\title{
Short-Term Faculty-Led Study Abroad Programs- Lessons from the CEU Business School New York City Program
}

Bala Mulloth, CEU Business School, Hungary

Mel Horwitch, CEU Business School, Hungary

Erin Newton, CEU Business School, Hungary

\begin{abstract}
It is increasingly clear that career aspirations of MBA students are changing. One shift is the type of firms they want to work with. Rather than large Fortune 500 companies, many MBA students now pursue roles with small and medium enterprises, and have entrepreneurial ambitions. Thus, there is a need to expose MBA students to a wide range of managerial and entrepreneurial options. Another major change is location. No longer do MBA students necessarily see their careers limited to a single city, a single country, or even a single continent. Instead, MBA students seek professional opportunities around the globe.

At Central European University Business School, in Budapest, Hungary, such forces have led to an increase in learning activities outside of the classroom, and beyond the school's home city. One significant example is a short-term faculty-led study abroad program in New York City that provides students with an immersive experience in the center of pacesetting management practices and entrepreneurial initiatives. This paper outlines the program and provides insights, lessons learned and recommendations for the future design of such programs.
\end{abstract}

\section{Introduction}

Business schools have been criticized for being insufficiently global and complacent. Their neglect can be seen as a disservice to their students (Financial Times, 2011; The Economist, 2011). On the other hand, some institutions have kept pace with the changing needs of management education and are redesigning their MBA programs to provide students with a global learning experience. Additionally, the business school educational community is also providing their members with increasingly sophisticated guides on what and how to teach globalization. Moreover, international study experiences are becoming more common (Horwitch and Stohr, 2012; AACSB, 2010).

One important way to educate MBA students for modern globalization and provide an entrepreneurial learning experience is to immerse such students in a pacesetting, global and entrepreneurial city. Such cities are now at the core of so-called "innovation clusters" (Moretti, 2012). Moreover, several theories, including industrial district theories, show that the university and its related activities are crucial sources for talent- ed and qualified employees (Markusen, 1996; Porter, 1990). As Vorley and Nelles (2008) emphasize, universities do not exist in a vacuum and gain strength from such innovation-rich settings.

In addition, universities worldwide are increasingly providing experiential learning opportunities, such as study abroad programs for their students. In fact, these programs have become a recruitment tool, as prospective students make institutional selection based on study abroad opportunities as well as academic offerings and campus life (Ludwig, 2000). Further, as businesses globalize and the demand for employees prepared for international assignments steadily increases, both students and faculties are recognizing the need to prepare for this new and interconnected world.

Study abroad programs, traditionally defined as all educational programs that take place outside the geographical boundaries of the country of origin, have increasingly gained popularity and interest in the last few years (Ozturgut, 2007). As Kitsantas (2004) states, historically, several studies have provided evidence that study abroad programs enhance students' worldview (Carlson \& Widman, 1988), global perspective (McCabe, 1994), cross-cultural effectiveness (Kitsantas \& Meyers, 2002), interest in travel, art, foreign languages, history and architecture (Carsello \& Creaser, 1976), and increase reflective thought, self reliance, self confidence and personal well being (Kuh \& Kaufman, 1984). Chieffo and Griffins (2003) observe that the majority of study abroad programs are now short-term and faculty-led.

Anderson et al (2006) provided an examination of literature relating to international programs and found that most overseas programs aim to achieve multiple developmental competencies. This study identified four typical areas that can be enhanced for students participating in an effective study abroad program: academic/intellectual, professional, personal and intercultural. The study also indicated that specific objectives established for study abroad programs vary from institution to institution; academic and intercultural competencies are common to virtually all programs. Academic competency focuses on the specific discipline studied, while intercultural competency relates to the broad goal of enhancing student appreciation of differences among cultures. Along with other studies (e.g. Kitsantas, 2004; Keese and O'Brien, 2011) it is clear that in essence, short-term faculty-led programs provide a unique opportunity for students to step outside the classroom and 
learn about the world firsthand, and for faculty to teach and mentor their students through a critical-learning and life-changing experience. Still, due to the multiple focus areas involved, developing a faculty-led short-term study abroad program is more demanding and involves a great deal more responsibility than planning and developing regular on-campus courses (Keese and O'Brien, 2011).

Responding to these trends and opportunities, Central European University (CEU) Business School, in Budapest, Hungary, developed and launched such a for-credit short-term faculty-led program, Business in a Global City: New York City, for its MBA students. In subsequent sections, we describe the program and identify critical issues involved in designing and implementing such a successful short-term faculty-led program. We then provide insights, lessons learned and recommendations for the future design of such programs.

\section{Business in a Global City: New York City}

"We want to serve, educate and nurture a global MBA community. Therefore, we believe that learning solely in a single location is increasingly unsuited for this larger purpose. We also feel that, at least up to now, virtual or technology-enabled learning does not provide a sufficiently rich learning experience. It is important for our students to experience an important and different business hub out of the classroom -in firms, cultural events and simply walking the streets of NYC."

\section{-Mel Horwitch, Dean, CEU Business School}

The development of Business in a Global City began in 2011 when Mel Horwitch, co-author of this paper and co-lead of the program, became the dean of CEU Business School. One of his mandates was to elevate the school's academic quality and reputation, and also to increase enrollment. Recognizing that exposure to business beyond the Central and Eastern European cities where many of CEU Business School students are from, would be one route to augment the school's curriculum and attract prospective students, Dean Horwitch proposed the creation of a weeklong course in New York City.

\section{Why New York City?}

There are pragmatic reasons why CEU Business School chose to have its first-ever study-abroad program in New York City. The school is a NY-charted institution, and it could leverage its standing as being both a US school and a European school. Because CEU Business School is aggressively trying to improve its academic offerings, it needed to choose a city in which it was feasible to prepare and organize a program from thousands of miles away within a relatively short amount of time: eight-months (from September 2011 when a faculty committee approved the course based on a preliminary description until lateApril 2012 when the course would start).

Dean Horwitch and Professor Bala Mulloth, also a co-author of this paper and co-lead of the program, lived and worked in New York City immediately prior to moving to Budapest and joining CEU Business School. Both have extensive networks of academic and professional contacts they could rely on to contribute to the program with short lead times. Their networks also ensured that they could arrange company site visits with high-level members of organizations. This was an important consideration for the design of the program as it was decided that students would derive much more value from meeting with and talking to executives and founders than by taking tours given by less entrenched members of an organization, which can be the case in some company site visits.

NYC is acknowledged as a global business capital, especially for media, finance, culture and global business management. Program creators believed that through systematic and careful curriculum design, and resulting academic exposure, its MBA students would quickly become more knowledgeable and enriched by having an immersive experience with modern management in a way that simply is not possible in Budapest.

Even more than being the center of leading management best practices, NYC is a pacesetting city in which the future of successful management strategies and principles are being developed today. Therefore, the program emphasized the "New, New York," characterized by three transformational and overlapping pillars likely to change the NYC economy and keep it robust: (1) the rise of clean technology as a major industry and managerial concern, (2) the emergence of a hightech segment in NYC (including analytics, software, social media, new media, etc.) and (3) the growth of an entrepreneurial cluster comprising for-profit entrepreneurs, social entrepreneurs, venture capitalists and private equity.

\section{Structure, Timing and Design of the Course}

Business in a Global City: New York City began as a combination of a week of study in New York City followed by a reflection session at CEU Business School's campus in Budapest. The essential elements of Business in a Global City include company visits across a variety of sectors-from finance and real estate to clean technology and media-and presentations by executives, entrepreneurs, consultants and other professionals who help to give context and perspective to contemporary business issues. The weeklong program is structured into "theme days" with students starting each day with one or more lectures delivered by a NYC-based expert in the day's theme, e.g., consulting, entrepreneurship, private equity. Students spend the second half of the day visiting a company involved in the same theme. (See Exhibit 1 for program schedule.)

When Business in a Global City ran for the first time in late April to early May in 2012 during a break in the academic year, 24 students in the executive MBA program and 11 students in the full-time program participated. A 20,000-euro grant from an anonymous member of the CEU Business School community subsidized the cost of the trip, with the funding going directly to students in the form of a 550-euro 
voucher they could apply to their costs as they wanted. A staff member at CEU Business School helped students secure visas for the many students who required them to enter the United Sates. The business school arranged for discounted hotel rates for students at a hotel near Polytechnic Institute of New York University in Downtown Brooklyn where the majority of lectures took place. While students were responsible for paying for their airfare, accommodations and meals, students incurred no additional tuition costs to participate in the short-term study abroad program.

The inaugural program included company visits to one of America's largest daily newspapers, a growth equity firm, and a clean-tech startup. Speakers included a serial entrepreneur, an independent business consultant and a sustainability expert. When Business in a Global City ran for the second time, it was in late April to early May 2013, also during a break in the academic year. Twenty-three students in the executive MBA program and four students in the full-time program participated. Instead of providing a grant to all students, the business school funded a scholarship that was given to students who submitted essays describing why they wanted to participate and the circumstances surrounding their need for a grant. Six of the students who applied for the grant received 600 euros each. As part of the scholarship, the students were required to write blog posts about their experience, one prior to arriving in New York City, one each day of the program, and one follow-up post when they returned to Budapest. (Erin Newton, an editor in CEU Business School's marketing department and co-author of this paper coordinated participants' blogging activities.)

As in the 2012 program, CEU Business School staff assisted students as they secured visas for the 2013 program, and there were no additional tuition fees for students to pay to participate. However, the business school did not organize for discounted hotel rates for the 2013 participants.

A notable programming change occurred in early 2013: students were contacted months before the program would run for their input on the companies and topics they wanted to be incorporated into the program. As much as possible, their requests were integrated.

During a week in May 2013, participants in Business in a Global City visited an international consulting company, a public-private research center and graduate school focused on big data analytics, and a growth equity firm, among other companies. Most of the lectures, which included speakers from a global pharmaceuticals company and an investment banking advisory firm, took place at the SUNY Levin Institute in Manhattan.

\section{Lessons Learned}

There are several lessons learned from running the NYC-program so far.

First, tacit knowledge of the location is extremely important. CEU Business School was fortunate in having two faculty members who had lived and worked in NYC for several years. As individuals they had developed deep knowledge of the city. They knew from their past professional work and research (both individuals study innovation and entrepreneurship) that NYC is a fast-changing city. While the large firms, especially in media and finance, remain strong, the high-tech, entrepreneurial community had started to boom, comprising an increasingly large share of NYC's employment. They understood that Mayor Michael Bloomberg's plan to transform NYC into a powerful innovation hub had traction, with many new firms springing up and a new major technology-based university being launched. Professor Mulloth had studied social entrepreneurship and sustainability and Professor Horwitch ran clean-tech executive education programs. So both knew that sustainability opportunities and concerns were also growing areas of endeavors in NYC. Finally, both could tap their wealth of NYC-based contacts to participate in the program.

Second, the explicit design of Business in a Global City benefited by a mutually reinforcing balance between best thinking and academics and a large portion of learning outside of the classroom. The general structure of lectures and readings discussed in the morning (often lead by managers and entrepreneurs) and related field and company visits in the afternoon appeared to be powerful as a learning model. The basic assignments were well integrated and supportive of the whole learning experience. Selected readings were assigned for each day, but the emphasis of the thinking was integrative and forward-oriented, focusing on the meaning of the program for the careers of the MBA participants. The students were explicitly asked to consider what they had learned that might be helpful for their careers, and wrote about and discussed what the program had meant for them professionally.

Third, and perhaps paradoxically, the very act of leaving Budapest temporarily to study in NYC, and of then returning to Budapest to complete the rest of the MBA program, actually appeared to refresh students' perspective of their Budapest home campus. Students seemed to have entered the final phase of their MBA program with renewed energy and purpose. Without incorporating Business in a Global City into the MBA program, the MBA program overall could have become increasingly routine as it wound down.

Finally, and even more fundamental, program leaders recognized that more time for self-organized activities (as individuals and as groups) would benefit participants, allowing them time to pursue their personal and professional interests, and leverage their time in New York City more fully. For example, many students wanted to explore professional opportunities in particular sectors. Others wanted deeper exposure to the strategies of certain NYC-based firms. And some students who were interested in creating startup ventures in Hungary, or other parts of the world, expressed interest in connecting with entrepreneurial ventures in NYC.

Consequently, after running the program in a one-week format in 2012 and in 2013, and based on overwhelmingly positive student feedback and a desire to build on this success, the school's faculty decided to expand BBusiness in a Global City into a month-long, multi-course program. This month-long program took place for the first time in spring 2014. The expanded program was worth significantly more MBA credits. Full-time MBA students attended for the full month; executive MBA students participated for one week, as before. The greatly enlarged 
program involved several CEU Business School faculty members and practitioners based in NYC. The longer format, which incorporated many of the same elements of the weeklong program, gave students even more time to be immersed in the New York business world.

\section{References}

AACSB International Globalization of Management Education Task Force. 2011. Globalization of Management Education: Changing International Structures, Adaptive Strategies, and the Impact on Institutions: Report of the AACSB International Globalization of Management Education Task Force. AACSB International (Ed.). Bingley, UK: Emerald Group Publishing.

Anderson, P. H., Lawton, L., Rexeisen, R. J., \& Hubbard, A. C. 2006. Shortterm study abroad and intercultural sensitivity: A pilot study. International Journal of Intercultural Relations, 30(4): 457-469.

Carley, S., Stuart, R., \& Dailey, M. P. 2011. Short-term study abroad: An exploratory view of business student outcomes. Journal of Management Policy and Practice, 12(2): 44-53.

Carlson, J. S., \& Widman, K. F. 1988. The effects of study abroad during college on attitudes toward other cultures. International Journal of Intercultural Relations, 12(1): 1-17.

Carsello, C., \& Greaser, J. 1976. How college students change during study abroad. College Student Journal, 10: 276-278.

Chieffo, L., \& Griffins, L. 2003. What's a month worth? Student perceptions of what they learned abroad. International Education, Fall: 26-31.

Financial Times. 2011. Top schools face globalisation challenge. March 6: http://www.ft.com/intl/cms/s/2/df3f8b34-467b-11e0aebf-00144feab49a.html\#axzz2grhCoL1v.

Horwitch, M., \& Stohr, E. A. 2012. Transforming technology management education: Value creation-learning in the early twentyfirst century. Journal of Engineering and Technology Management, 29(4): 489-507.

Keese, J. R., \& O'Brien, J. 2011. Learn by going: critical issues for faculty-led study-abroad programs. The California Geographer, 51: 91-113.

Kitsantas, A. 2004. Studying abroad: The role of college student's goals on the development of cross-cultural skills and global understanding. College Student Journal, 38(3): 441-452.

Kitsantas, A., \& Meyers, J. 2002. Studying abroad: Does it enhance college student cross-cultural awareness? Educational Resources Information Center, ED 456-648.

Kuh, G.K., \& Kauffman, N.F. 1984. The impact of study abroad on personal development of college students. Bloomington, IN: Indiana University School of Education. (ED 245 591).
Ludwig, M. 2000. The next ten years: Trends affecting study abroad participation for US students. International Educator, 9(4): 34-40.

Markusen, A. 1996. Sticky places in slippery space: a typology of industrial districts. Economic Geography, 72(30: 293-313.

McCabe, L. T. 1994. The development of a global perspective during participation in semester at sea: A comparative global education program. Educational Review, 46(3): 275-286.

Moretti, E. 2012. The New Geography of Jobs. New York: Houghton Mifflin Harcourt.

Ozturgut, O. 2007. Study/teach abroad programs for higher education faculty. Essays in Education, 22: 42-49.

Porter, M. E. 1996. Competitive advantage, agglomeration economies, and regional policy. International Regional Science Review, 19(1-2): 85-90.

The Economist. 2011. Business schools and globalization — Promising the world. September 29: http://www.economist.com/blogs/ whichmba\%3F/2011/09/pankaj-ghemawat.

Vorley, T., \& Nelles, J. 2008. Institutional development of and beyond the third mission. Higher Education Management and Policy, 20(3): 119.

Bala Mulloth (mullothb@ceubusiness.org) is assistant professor of entrepreneurship and innovation management at Central European University (CEU) Business School. His main research focus is in entrepreneurship and innovation, particularly in the areas of social entrepreneurship and the development of global innovation ecosystems. He has published articles in well-regarded journals. He teaches courses on new venture development, social entrepreneurship, and sustainability in business. He holds a PhD in Technology Management from Polytechnic Institute of New York University.

Mel Horwitch (mhorwitch@ceubusiness.org) is Dean and University Professor at Central European University (CEU) Business School. He is an acknowledged expert on entrepreneurship and innovation management and. He has written extensively on technology strategy, particularly with reference to knowledge-intensive sectors, global innovation, the role of networks and cross-boundary and multi-sector endeavors in developing technology. He received his $A B$ from Princeton University, MBA and Doctorate from Harvard Business School, and was a Peace Corps Volunteer in Thailand.

Erin Newton (erin.leigh.newton@gmail.com) is an experienced communications professional, specializing in developing content and platforms for initiatives in higher education. She works closely with educators, writers, designers, and programmers to build websites and other materials that inform and engage. Ms. Newton holds a Master of Arts in Professional Writing from Carnegie Mellon University and a Bachelor of Arts in English from Northeastern University. 
Exhibit 1. Program Schedule, 2013

\begin{tabular}{|c|c|c|c|c|c|c|c|c|c|c|}
\hline $\begin{array}{l}\text { Fri. } \\
4 / 26\end{array}$ & $\begin{array}{l}\text { Sat. } \\
4 / 27\end{array}$ & $\begin{array}{l}\text { Sun. } \\
4 / 28\end{array}$ & $\begin{array}{l}\text { Mon. } \\
4 / 29\end{array}$ & $\begin{array}{l}\text { Tues. } \\
4 / 30\end{array}$ & $\begin{array}{l}\text { Wed. } \\
5 / 1\end{array}$ & $\begin{array}{c}\text { Thurs. } \\
5 / 2\end{array}$ & $\begin{array}{l}\text { Fri. } \\
5 / 3\end{array}$ & $\begin{array}{l}\text { Sat. } \\
5 / 4\end{array}$ & $\begin{array}{l}\text { Sun. } \\
5 / 5\end{array}$ & $\begin{array}{c}\text { Mon. } \\
5 / 6\end{array}$ \\
\hline \multirow[t]{3}{*}{$\begin{array}{l}\text { Leave } \\
\text { for New } \\
\text { York } \\
\text { City }\end{array}$} & $\begin{array}{l}\text { Free time } \\
\text { to explore } \\
\text { NYC }\end{array}$ & $\begin{array}{l}\text { Free time } \\
\text { to explore } \\
\text { NYC }\end{array}$ & $\begin{array}{l}\text { 9:00am-12:00pm: } \\
\text { The Rise of a Global } \\
\text { Entrepreneurial City }\end{array}$ & $\begin{array}{l}\text { 9:00am-12:00pm: } \\
\text { Overview Emerg- } \\
\text { ing Major Trends in } \\
\text { Business Opportu- } \\
\text { nities in NYC }\end{array}$ & $\begin{array}{l}\text { 9:00am-12:00pm: } \\
\text { Professional services } \\
\text { industry in NYC: } \\
\text { Consulting, Finance }\end{array}$ & $\begin{array}{l}\text { 9:00am-12:00pm: } \\
\text { Multinational emerg- } \\
\text { ing market strategies }\end{array}$ & $\begin{array}{l}\text { 9:00am-12:00pm: } \\
\text { The Rise \& Practice } \\
\text { of the Urban Clean- } \\
\text { tech/Sustainability } \\
\text { Sector }\end{array}$ & $\begin{array}{c}\text { Free time } \\
\text { to explore } \\
\text { NYC }\end{array}$ & & $\begin{array}{l}\text { Arrive in } \\
\text { Budapest }\end{array}$ \\
\hline & & & Lunch on own & Lunch on own & Lunch on own & Lunch on own & Lunch on own & & & \\
\hline & & & $\begin{array}{l}\text { Company visits: } \\
\text { 1:00-2:30pm: } \\
\text { Professional Consult- } \\
\text { ing Company } \\
\text { 3:00-4:30pm: } \\
\text { Advanced Urban } \\
\text { Technology Think } \\
\text { Tank }\end{array}$ & $\begin{array}{l}\text { Company visit: } \\
\text { 2:00-3:30pm: } \\
\text { Private Equity Firm }\end{array}$ & $\begin{array}{l}\text { Company visit: } \\
\text { 2:30-4:00pm } \\
\text { High Tech Business } \\
\text { Incubator }\end{array}$ & $\begin{array}{l}\text { Company visit: } \\
\text { 3:00-4:30pm: } \\
\text { Clean-tech Venture }\end{array}$ & $\begin{array}{l}\text { Afternoon Free for } \\
\text { Individual Profes- } \\
\text { sional Opportuni- } \\
\text { ties }\end{array}$ & & $\begin{array}{l}\text { Return } \\
\text { flights }\end{array}$ & (no classes) \\
\hline & & $\begin{array}{l}\text { Program } \\
\text { Launch: } \\
\text { Welcome } \\
\text { Drinks }\end{array}$ & Dinner on own & Dinner on own & Dinner on own & Group Dinner & Dinner on own & $\begin{array}{c}\text { Dinner on } \\
\text { own }\end{array}$ & & \\
\hline
\end{tabular}

